\title{
THE COMING CRIME WAVE? AIDS, ORPHANS AND CRIME IN SOUTH AFRICA
}

\author{
Martin Schönteich \\ Institute for Security Studies, Pretoria
}

\section{INTRODUCTION}

Crime levels in South Africa are likely to increase over the next two decades because of the HIV/AIDS epidemic. The epidemic will result in an unprecedented increase in the country's orphan population. Growing up without parents, and badly supervised by relatives and welfare organisations, this growing pool of orphans will be at greater than average risk of engaging in criminal activity. Many orphans will also be vulnerable to victimisation.

In addition, HIV/AIDS will detrimentally affect the criminal justice system's effectiveness. With an increasing number of police officers, prison wardens and court personnel falling ill and dying, the state's ability to fight crime, and punish and rehabilitate offenders will be undermined.

\section{OVERWHELMING CAREGIVERS}

South Africa has the largest population of HIV-positive people in the world. It is estimated that 6 million South Africans will die from the epidemic by 2010. ' In contrast to most infectious diseases, which target the elderly and the very young, HIV/AIDS takes its greatest toll among young adults. The expected wholesale death of young adults in South Africa is producing orphans on a scale unprecedented in the country's history.

Nearly 1 million South African children under the age of 15 years will have lost their mother or both parents to AIDS by 2005. The Department of Health $(\mathrm{DOH})$ estimates that this figure will increase to over 2 million by $2010 .^{2}$

Historically, large-scale orphaning has been a sporadic, short-term problem caused by war, famine or disease. The HIV/AIDS epidemic has transformed it into a long-term chronic problem that will extend at least through the first third of the twenty-first century. This is because the increase in orphan rates lags behind HIV infection levels by about 10 years, the time it takes the average person who contracts the virus to die from full-blown AIDS.

As the AIDS epidemic progresses there will be fewer adults of normal parenting age to care for the children they leave behind. The burden of care will increasingly fall on other children or on the growing proportion of elderly people.

However, the large number of anticipated AIDS orphans has led the United Nations International Children's Emergency Fund (UNICEF) to conclude that Africa's age-old social safety net for such children - in the form of deep-rooted kinship systems and extended family networks - is unable to cope with the strain of AIDS and soaring numbers of orphans in the most affected countries: 'Capacity and resources are stretched to breaking point, and those providing the necessary care in many cases are already impoverished, often elderly and might themselves have depended financially and physically on the support of the very son or daughter who has died.'

A number of studies have been conducted on the plight of orphans and their caretakers in various African countries. It has been shown that families that foster children in Kenya usually live below the poverty line, and that orphan households in Tanzania have more children, are larger, and have less favourable dependency ratios than non-orphan households. ${ }^{5}$

Orphans run greater risks of being malnourished and stunted than children who have parents to look after them. ${ }^{6}$ They are also the first to be denied education when extended families cannot afford to educate all the children of the household. This lack of schooling, often combined with poor nutrition, makes it particularly difficult for orphans to escape poverty?

\section{ORPHANS AND CRIME}

\section{POVERTY AND URBANISATION}

The many orphaned South African children who will grow up under extreme levels of poverty will be sorely tempted or even obliged for the sake of their physical survival - to commit a range of property-related crimes. These crimes will include the theft of food and clothing by shoplifting and residential burglary, or the theft of other items which can be sold or traded for food, clothing or other necessities. Older orphans in their early teenage years might resort to mugging and robbery to make ends meet. 
The migration of children to urban centres has long been observed in developing countries, including South Africa, because of high rural unemployment and poverty levels. ${ }^{8}$ This trend is likely to increase as the epidemic escalates and leaves large numbers of orphans in its wake. A significant number of child migrants flocking to their nearest city will increase the already high numbers of street children in South Africa.

Street children are both the cause and victims of a range of crimes. Petty thefts, muggings, burglaries and theft out of motor vehicles are crimes commonly associated with street children. Many such children are assaulted, abused, raped and drawn into prostitution rings.

A large influx of orphaned children into the urban slums surrounding many South African cities will exacerbate socio-economic conditions, thereby creating a vibrant breeding ground for a variety of social ills such as crime. Moreover, certain types of crime, such as gang-related crimes, vehicle thefts, robberies and burglaries, are higher in cities than in rural areas, with the rate generally increasing according to city size.

Moreover, most factors associated with high crime rates characterise cities to a greater extent than small towns or rural villages. Population density, for example, is thought to be associated with crime in that greater concentrations of people lead to competition for limited resources, greater stress and increased conflict. Factors that characterise urbanisation such as overcrowding and increased consumer demands and expectations are themselves believed to be associated with high crime rates. High levels of gang activity and the availability of firearms are also mainly evident in urban areas and are known to be related to criminal activity. ${ }^{9}$

\section{PSYCHOLOGICAL TRAUMA}

Children who lose a parent to AIDS suffer loss and grief like any other orphan. However, their loss is exacerbated by prejudice and social exclusion, and can lead to the loss of education and health care. ${ }^{10}$ That is, the shame, fear and rejection that often surrounds people affected by HIVIAIDS can create additional stress and isolation for children, both before and after the death of their parent or parents.

The psychological impact on a child who witnesses his or her parent dying of AIDS can be more intense than for children whose parents die from more sudden causes. According to UNAIDS: 'HIV ultimately makes people ill but it runs an unpredictable course. There are typically months or years of stress, suffering or depression before a patient dies. And in developing countries, where the epidemic is concentrated, effective pain or symptom relief is often unavailable to alleviate a parent's suffering."t
Moreover, for a child living with a parent who has AIDS, the disease is especially cruel as HIV is sexually transmitted. Consequently, once one parent is infected, he or she is likely to pass it on to the other parent. Children who lose a parent to AIDS are therefore at considerable risk of losing their remaining parent as well. Children consequently have to take on the role of mother, father or both, doing housework, farming and caring for their siblings and their ill or dying parents, "bringing on stress that would exhaust even adults.'.2

A report prepared for UNICEF identifies a set of experiences commonly affecting most AIDS orphans:

- trauma associated with losing a parent, which is in most cases exacerbated by the threat of losing the second parent

witnessing the parent's physical deterioration, pain and death

- caring for a parent in his or her terminal phase and often being blamed for causing pain

anxiety about source of livelihood and ability to retain the family home after the parent's death..$^{13}$

Research commissioned by the Nelson Mandela Children's Fund found that South African AIDS orphans are being ostracised by their communities and exploited financially by relatives who had taken them in, primarily to receive a state grant. Emotionally, the orphans were found to be suffering as a result of the deprivation of parental guidance, emotional trauma as a result of loss, and the problem of having to cope with adult responsibilities prematurely. The research found that orphans were also vulnerable to physical and sexual abuse by neighbours and relatives.

\section{DELINQUENCY AND CRIME}

A South African DOH publication, ${ }^{15}$ which looks at the impact of AIDS in South Africa, predicts that children orphaned because of AIDS could be at risk of engaging in delinquent behaviour: 'As [orphaned] children under stress grow up without adequate parenting and support, they are at greater risk of developing antisocial behaviour and of being less productive members of society.

Ashraf Grimwood of the National AIDS Coalition in South Africa argues that the increasing number of AIDS orphans, who grow up without parental support and supervision, will turn to crime: 'Crime will increase because of the disintegration of the fabric of our society. It will be made worse by the lack of guidance, care and support for HIVpositive people, including children. Children orphaned by AIDS will have no role models in the future and they will resort to crime to survive.

A review of the backgrounds of a large sample of children 
who have killed or committed other grave (usually violent) crimes in the UK found that 57\% had experienced the death, or loss of contact, of someone important such as a parent.

A 1998 interview study of young men serving jail sentences, or involved in crime, by the Centre for the Study of Violence and Reconciliation (in South Africa) found that most of the interviewees were 'abandoned or kicked out of their homes, or... had to live with a stepfather or mother who rejected them. Many expressed feelings of being unloved.' ${ }^{\prime 6}$

The absence of a father figure early in the lives of young males tends to increase the incidence of delinquency later on. Moreover, such an absence will directly affect a boy's ability to develop self-control. The secure attachment or emotional investment process [a father figure provides] facilitates the child's ability to develop and demonstrate both empathy and self-control. By extension, an insecure attachment will lead to lower levels of empathy and selfcontrol, and to an increase in violent behaviour.2

Since the early 1990 s reports from government commissions, research reports, and syntheses produced by national crime prevention organisations have identified a number of common factors associated with delinquency, violence and insecurity:2t

- poverty and unemployment deriving from social exclusion, especially for youth

aysfunctional families with uncaring and inconsistent parental attitudes, violence or parental conflict

- discrimination and exclusion deriving from one or other form of oppression

-1. degradation of urban environments and social bonds

- social acceptance of a culture of violence

- presence of exacerbating factors such as firearms and drugs.

All of the above factors apply to a large proportion of AIDS orphans in South Africa. Such orphans grow up impoverished, tend to be socially excluded, are not properly cared for because of the loss of their parent(s), are often discriminated against, and grow up in an environment where social bonds are falling apart because of the high AIDS-related mortality rates among all segments of society.

If would appear that the kind of psychological trauma and lack of parental affection and supervision experienced by AIDS orphans is a good predictor of subsequent delinquency and violent criminal behaviour.

Insufficient research has been done on the extent of the risk AIDS orphans face of engaging in antisocial and violent behaviour later in their lives. However, given that there will be some 2 million AIDS orphans in South Africa by 2010, it is conceivable that there will be a significant increase in violent interpersonal crime such as murder, rape and assault, violent property crime such as robbery, and violent crime against property such as malicious injury to property.

\section{ORPHANS AS VICTIMS}

The HIV/AIDS epidemic can also lead to crime in more direct ways, with orphans and other vulnerable children becoming victims. The belief that sex with a virgin can cure HIV/AIDS appears to be widespread. ${ }^{22}$ In South Africa, 25\% of young people do not know that this is a myth. ${ }^{23}$ Moreover, rapists are also targeting young girls in the belief that being less sexually active, they are less likely to have HIV or AIDS. ${ }^{24}$

A study conducted among urban South African township youth in 1996 found that for the youth the knowledge that they were infected with HIV, or merely believed that they might be infected, 'was accepted not only as a death sentence but also as a passport to sexual licence..25 That is, some youths argued that they would actively spread the HIV virus among as many people as possible if they themselves were infected with HIV - a philosophy of 'infect one, infect all.' Young women expressed a general fear that men would respond to an HIV-positive diagnosis by raping women. 26

\section{WEAKENING CRIMINAL JUSTICE SYSTEM}

Unexpectedly, and largely unrecognised by criminal justice policy makers, HIV/AIDS could significantly impact on the criminal justice system's effectiveness.

It is likely that the administration of justice will suffer under the onslaught of the epidemic. As more people fall ill and die of AIDS, fewer criminal trials will be finalised. Presently it takes about 6 months for a trial to be finalised in the country's magistrates' courts. Within the coming decade, when one in five South Africans will be infected and ill with the virus many trials will be delayed - or will have to be stopped altogether - because the accused, his witnesses, the state's witnesses or one of the court officials is likely to be ill, dying or dead because of the disease. As the wheels of justice turn even more slowly than they do now, and as justice will often not be done because of the non-completion of trials, further impetus could be given to vigilante organisations with their promise of swift and effective 'justice'.

The epidemic will affect the South African Police Service and the department of correctional services particularly badly as many of their operational staff are young adults who are in the high-risk group when it comes to infection. Already understaffed, these services will function even less optimally than they do today as absenteeism because of 
illness, and high mortality rates among staff members, increase.

Over the next decade the political pressure on the government to devote more resources to health and welfare services will increase. This, and the negative effect the epidemic will have on the economy generally, is likely to curtail state spending on the criminal justice system. Under-resourced and operating with a high number of ill personnel, some operational activities of the criminal justice system could stop functioning altogether.

\section{CONCLUSION}

South Africa's growing number of AIDS orphans are likely to be significant contributors to future crime levels. Governmental policy makers would be well advised to brace themselves for an increase in juvenile crime as the number of orphaned juveniles increases over the next two decades. Traditional methods of fighting crime, such as tougher laws, more police officers, and more prisons will do little to counter this.

What is required is a programme of action that will involve not only key government departments comprising the criminal justice system (police, justice, and corrections), but also departments such as health, welfare, and education.

Moreover, relevant non-governmental organisations (NGOs) and organs of civil society need to get involved to develop strategies to combat the anticipated increase in crime committed by AIDS orphans effectively. Adequately staffed and resourced juvenile detention centres, rehabilitation and diversion programmes for young offenders, and an effective children's court system will have to feature more prominently on governments' list of priorities in the future.
REFERENCES

1. Shell R. Halfway to the holocaust: the economic, demographic and social mplications of the AIDS pandemic to the year 2010 in the southern African region. Occosional Papers, June 2000. Johannesburg: Konrad Adenauer Stiftung: 22.

2. Kinghorn A, Steinberg M. HIV/AIDS in South Africa: The Impact and the Priorities. Department of Health, 1999: 14

3. Hunter S, Williamson J. Children on the Brink. Updated Estimates and Recommendations for Intervention. Executive summary. Washington, DC: USAID, 2000: 1.

4. United Nations International Children's Emergency Fund. Children Orphoned by AIDS. Front-line Responses from Eostern and Southern Africa. New York: UNICEF, 1999: 3.

5. Myslik WD, Freeman A. Slawski J. Implications of AIDS for the Southern African population age profile. Southern African Journal of Gerontology 1997; $6(2): 6$.

6. A World Bank policy research report Confronting AIDS. Public Priorities in a Global Epidemic New York: Oxford University Press, 1999: 223-224.

7. A World Bank policy research report. Confronting AIDS. Public Priorities in a Global Epidemic New York: Oxford University Press, 1999: 225-227.

8. Michael K. Understanding the urban impact of HIVIAIDS-associated orphanhood, in AIDS orphans in Africa. Building an urban response. Johannesburg: Centre for Policy Studies, 2001: 25.

9. Glanz L South African cities under siege. Durban: Indicator Crime and Conflict, No. 2. 1995: 17 .

10. The Orphans of AIDS: Breaking the Vicious Circle <http://www.unaids.org/ unaids/events/wad/1997/orphansofaids.html>.

11. Children Orphaned by AIDS. <http://www.unaids.org/unaids/events/wad/ 1997/orphanthtmi>.

12. United Nations Children's Emergency Fund. Children Orphaned by AIDS. Front-line Responses from Eostern and Southern Africa, New York: UNICEF, 1999: 5.

13. Loening-Voysey H, Wilson T. Approoches to Caring for Children Orphaned by AIDS and Other Vulnerable Children. Johannesburg: Institute for Urban Primary Health Care, 2001.

14. Thompson C. AlDS orphans in dire need. The Citizen 2001; 25 June.

15. Kinghorn A, Steinberg M. HIV/AIDS in South Africa: The Impoct and the Priorities. Pretoria: Department of Health, 15.

16. Mackay M M. Aids will spur on crime, say experts. Saturday Argus 1999; 9 January

17. Why do children become violent? Innocenti Digest, Children and Violence, no. 2. Florence: UNICEF International Child Development Centre, 15.

18. Segal L, Pelo J, Rampa P. Asicamtheni magents - Let's talk, magents. Youth attitudes towards crime. Crime and Conflict, no. 15, Autumn 1999. Durban: University of Natal: 24.

19. Bowlby J. Forty-four Juvenile Thieves: Their Characters and Home Life. London: Bailliere, Tindall and Cox, 1947.

20. Katz RS. Building the foundation for a side-by-side explanatory model: A general theory of crime, the age-graded life-course theory, and attachment theory. Western Criminology Review, 1999; 1(2): Online: <http://wcr.sonoma.edu/ vin2/katzhtml> (5 May 1999).

21. Crime Prevention Digest II. Comparative Analysis of Successful Community Safety. Montreal: International Centre for the Prevention of Crime, 1999: 20-21

22. Leclerc-Madiala S. Crime in an epidemic: the case of rape and AIDS. Acto Criminologica, Vol 9, No 2. Pretoria: Criminological Society of South Africa, 1996: 35.

23. Lovelife, Hot Prospects, Cold Focts, Johannesburg: Colorpress, South Africa, 2000.

24. Leclerc-Madiala S. Crime in an epidemic: the case of rape and AIDS. Acto Criminologica, Vol 9, No 2. Pretoria: Criminological Society of South Africa, 1996: 35-36.

25. Lecierc-Madlala S Crime in an epidemic: the case of rape and AIDS. Acto Criminologica, Vol 9, No 2. Pretoria: Criminological Society of South Africa, 1996: 32.

26. Leclerc-Madlala S. Crime in an epidemic: the case of rape and AIDS. Acto Criminologica, Vol 9, No 2. Pretoria: Criminological Society of South Africa, 1996: 33-34. 